DOI: $10.19195 / 0524-4544.325 .12$

\title{
EDYTA WŁODARCZYK
}

ORCID: 0000-0003-2268-1268

Uniwersytet Wrocławski

edyta.wlodarczyk@uwr.edu.pl

\section{Wizytacje wyższych seminariów duchownych przez władze państwowe w Polsce w latach 1960-1971}

\section{Wstęp}

Po II wojnie światowej sprawę prywatnego szkolnictwa wyższego regulowała ustawa z 22 lutego 1937 roku o prywatnych szkołach wyższych ${ }^{1}$, która w całości poddawała prywatne szkoły wyższe pod nadzór i opiekę Ministerstwa Oświaty i Wychowania ${ }^{2}$. Na mocy art. 17 tej ustawy spod takiego nadzoru wyłączone były seminaria duchowne, zarówno diecezjalne, jak i zakonne, utrzymywane na mocy

1 Dz.U. RP Nr 13, poz. 89.

2 „Ustawa z dnia 22 lutego 1937 roku o prywatnych szkołach wyższych (Dz.U. Nr 13, poz. 89) weszła w życie od dnia 26 lutego 1937 roku, a została uchylona z dniem 30 października 1947 roku na mocy art. 119 ust. 2 pkt 3 dekretu z dnia 28 października 1947 roku o organizacji nauki i szkolnictwa wyższego (Dz.U. Nr 66, poz. 415). Ustawa [z 22 lutego 1937 roku - E.W.] na wstępie w art. 1 stanowiła, że za prywatne szkoły wyższe w rozumieniu jej przepisów należy uważać te prywatne szkoły wyższe, które nie były objęte ustawą z dnia 15 marca 1932 roku o szkołach akademickich. [...] Nadzór nad prywatnymi szkołami wyższymi sprawował Minister Wyznań Religijnych i Oświecenia Publicznego. Pierwszą, najważniejszą, formą tego nadzoru było zatwierdzanie statutu szkoły przez ministra, który mógł w ten sposób poważnie ograniczyć autonomię szkoły. [...] Ustawa o prywatnych szkołach wyższych z 1937 roku miała charakter epizodyczny, nie regulowała wszystkich kwestii związanych z ich organizacją i zarządzaniem. Nie do końca precyzyjnie określony był jej stosunek do ustawy o szkołach akademickich z 1933 roku, zwłaszcza w odniesieniu do szkół, które uzyskały status szkół akademickich, co nie pozostawało bez wpływu na ich organizację i zarządzanie". J. Koredczuk, Zarządzanie prywatnymi szkołami wyższymi w Polsce w okresie międzywojennym, [w:] Zarządzanie szkoła wyższa, red. J. Blicharz, A. Chrisidu-Budnik, A. Sus, Wrocław 2004, s. 13-20. 
art. XIII Konkordatu między Polską a Stolicą Apostolską. Konkordat z 1925 roku dawał Kościołowi katolickiemu w Polsce prawo do prowadzenia w każdej diecezji seminarium duchownego ${ }^{3}$. Seminaria duchowne nie zostały zatem podporządkowane przepisom dekretu z 28 października 1947 roku o organizacji nauki i szkolnictwa wyższego ${ }^{4}$, który nakazywał, by „szkoły niepaństwowe działające na podstawie dotychczasowych przepisów, w ciągu sześciu miesięcy od dnia wejścia dekretu w życie przedłożyły wnioski i dane przewidziane w dekrecie"5. Władze państwowe uznawały wówczas seminaria duchowne za zakłady zamknięte, przez co w rezultacie same pozbawiły się możliwości kontroli i nadzoru nad działalnością tych szkół. Seminaria, ze względu na swój status społeczny, znacząco odbiegały w swej strukturze od standardów szkół państwowych, gdyż zgodnie z ustawą z 11 marca 1932 roku o ustroju szkolnictwa ${ }^{6}$ były zakładami prywatnymi nieutrzymywanymi ani przez państwo, ani samorząd, lecz przez Kościół i podlegały przepisom prawnym dotyczącym prywatnego szkolnictwa.

Przykład może stanowić tutaj wyższe seminarium duchowne w Częstochowie, które po II wojnie światowej wznowiło swoją działalność. Od 1926 do 1954 roku alumni częstochowskiego WSD studiowali w Krakowie, a sama uczelnia włączona była w struktury Wydziału Teologicznego Uniwersytetu Jagiellońskiego. W 1954 roku władze komunistyczne zlikwidowały Wydział Teologiczny na Uniwersytecie Jagiellońskim i tym samym uczelnię wyłączono ze struktur uniwersytetu. Na skutek tego bp Zdzisław Goliński zorganizował studium domesticum, w którym zajęcia prowadzili kapłani z diecezji częstochowskiej. Profesorem w seminarium był w tym czasie ks. doc. dr hab. Karol Wojtyła ${ }^{7}$.

Jak podaje Andrzej Szymański w swojej publikacji pt. Inwigilacja kadry i alumnów Wyższego Seminarium Duchownego we Wrocławiu przez Urząd Bezpieczeństwa Publicznego w latach 1953-1954, w listach pasterskich kierowanych $\mathrm{z}$ różnych okazji do wiernych biskupi podkreślali wielokrotnie, że seminarium duchowne jest sercem diecezji, od którego zależy żywotność lokalnych wspólnot katolickich. W realiach Polski Ludowej placówki naukowe kształcące kandyda-

${ }^{3}$ H. Misztal, Polskie prawo wyznaniowe, Zagadnienia wstepne. Rys historyczny, t. 1, Lublin 1996, s. 125-127; J. Związek, Z dziejów Częstochowskiego Seminarium Duchownego w Krakowie (1926-1991), „Veritati et Caritati” 6, 2016, s. 353.

4 Dz.U. Nr 66, poz. 415.

5 D. Zamiatała, Zakony męskie $w$ polityce władz komunistycznych $w$ Polsce $w$ latach 19451989, t. 1. Problematyka organizacyjno-personalna, Łomianki 2011, s. 586.

6 Dz.U. RP Nr 38, poz. 389.

7 „Po utworzeniu Papieskiego Wydziału Teologicznego i Papieskiej Akademii Teologicznej w Krakowie Częstochowskie Seminarium Duchowne było związane z tymi uczelniami specjalnymi umowami, dzięki czemu klerycy częstochowscy mogli uzyskać stopień naukowy magistra teologii, a częstochowscy pracownicy naukowi mogli zdobywać awanse akademickie. Szczególnie o przynależność do krakowskich uczelni kościelnych dbał bp częstochowski Stefan Bareła. W tym czasie przełożeni i pracownicy naukowi w Seminarium cieszyli się dużym szacunkiem i prestiżem zarówno u władzy diecezjalnej, jak i duchowieństwa częstochowskiego". J. Związek, op. cit., s. 415. 
tów do stanu duchownego na poziomie średnim i wyższym, czyli niższe i wyższe seminaria duchowne (WSD), z tych właśnie względów znalazły się w centrum zainteresowania aparatu bezpieczeństwa ${ }^{8}$.

W lutym 1950 roku pojawiły się pierwsze próby poddania części seminariów duchownych kontroli państwa, a konkretnie Ministerstwa Oświaty, na podstawie art. 96-107 dekretu z 28 października 1947 roku mówiące o organizacji nauki i szkolnictwa wyższego. Chodzi dokładnie o WSD księży misjonarzy w Krakowie, jezuitów w Lublinie oraz diecezjalne w Tarnowie, Przemyślu, Lublinie, Pelplinie, Poznaniu, Płocku i Włocławku9 . Pozostałe seminaria wyższe i niższe miały podlegać kontroli kuratoriów szkolnych zgodnie z ustawą z dnia 11 marca 1932 roku o prywatnych szkołach oraz zakładach naukowych i wychowawczych $^{10}$. Opierając się na tych aktach prawnych, władze chciały przyznać sobie prawa do zatwierdzania statutów, programów i planów nauczania, nominacji personelu nauczającego oraz stałej kontroli nad wykonywaniem programów w seminariach ${ }^{11}$. Ponadto wykładowców seminariów objęto działaniem dekretu z dnia 9 lutego 1953 roku o obsadzaniu stanowisk duchownych ${ }^{12}$.

Również aparat bezpieczeństwa domagał się podporządkowania państwu seminariów duchownych. Wszystkie przedstawione postulaty i plany pozostawały jednak w fazie projektów i aż do roku 1959 władze państwowe nie rościły sobie żadnych praw do kontroli WSD, uznając je za szkoły wyższe.

$\mathrm{Na}$ przełomie lat 50. i 60. władze partyjno-państwowe wprowadziły nowe elementy $\mathrm{w}$ walce $\mathrm{z}$ seminariami duchownymi kształcącymi przyszłych duchownych, a mianowicie zastosowano między innymi drastyczną politykę podatkową i majątkową, a kleryków powoływano do zasadniczej służby wojskowej. Po od-

8 A. Szymański, Inwigilacja kadry i alumnów Wyższego Seminarium Duchownego we Wrocławiu przez Urząd Bezpieczeństwa Publicznego w latach 1953-954, „Przegląd Prawa Wyznaniowego" 10, 2018, s. 57.

9 D. Zamiatała, op. cit., s. 587.

10 Dz.U. RP Nr 33, poz. 343.

11 Urzędy do spraw wyznań informacji o wyższych i niższych seminariach duchownych dochodziły również, powołując się na art. 24 Prawa o stowarzyszeniach (Dz.U. RP z 1932 r. Nr 94, poz. 808 ze zm.). Chodziło o następujące dane: „1. Skład wyższych i małych seminariów zakonnych (oddzielnie dla każdego seminarium) z podaniem: imion i nazwisk, tytułów naukowych oraz pełnionych funkcji. 2. Skład grona nauczającego z wyszczególnieniem: imion, nazwisk, rodzaju ukończonych studiów, rodzaju specjalizacji, wykazu wykładanych przedmiotów przez każdego z nich. 3. Ilość wydziałów (jakie - nazwa) z podaniem lat studiów, specjalizacji i wykazem wykładanych przedmiotów. 4. Ilość słuchaczy w poszczególnych seminariach, na poszczególnych wydziałach i latach studiów. 5. Sposób przyjmowania kandydatów do seminariów zakonnych (egzamin wstępny, skierowanie itp.). 6. Liczba absolwentów wyższego seminarium duchownego w latach szkolnych 1955/56, 1956/57 i 1957/58. 7. Liczba absolwentów niższego seminarium duchownego w latach szkolnych 1955/56, 1956/57 i 1957/58”. List Urzędu do Spraw Wyznań do Zgromadzenia Pallotynów w sprawie nadestania danych o seminariach duchownych z dnia 10 marca 1959 r., [w:] P. Raina, Kościót katolicki a państwo w świetle dokumentów 1945-1989, t. 1. Lata 1945-59, Poznań 1994, s. 681.

12 Dz.U. Nr 9, poz. 32. 
wilży październikowej w 1956 roku działalność skierowaną przeciwko Kościołowi realizowano planowo i metodycznie - do roku 1959 prowadzono głównie akcję inwigilacyjną i różnego typu utrudnienia wdrażane przez władzę, jednak WSD mogły funkcjonować w miarę normalnie ${ }^{13}$. W latach 1944-1959 nie odnotowano również przypadku nadzoru państwowego nad wyższymi seminariami. Władze państwowe nie wysuwały takich roszczeń ani też nie podejmowały żadnych prób w tym kierunku ${ }^{14}$.

Zmiana nastąpiła dopiero w 1959 roku, gdy władze komunistyczne uzmysłowiły sobie, że swoboda kształcenia i wychowywania kandydatów na kapłanów była kwestią niezwykle kłopotliwą i pozostawała poza zupełną kontrolą państwa. Przekonanie, że w seminariach Kościół kształci alumnów w atmosferze wrogiej państwu ludowemu i kształtuje się tam poglądy wrogie interesom społecznym, pchnęło władze ludowe do działań zmierzających do kontroli $\mathrm{WSD}^{15}$.

13 A. Szymański, op. cit., s. 58.

14 A. Mezglewski, Szkolnictwo wyznaniowe w Polsce w latach 1944-1980, Lublin 2004, s. $72-73$.

15 Instytut Pamięci Narodowej Oddział Wrocław (IPN Wr), sygn. akt 032/26 t. 1-3, Notatka Informacyjna Zastępcy Komendanta Wojewódzkiej Komendy Milicji Obywatelskiej we Wrocławiu z dnia 30 marca 1957 roku, k. bd.

,zupełna swoboda kształcenia i wychowywania kandydatów do stanu duchownego, jaką Państwo pozostawiło władzom kościelnym i zakonnym, była i jest wykorzystywana w sposób budzący zasadnicze zastrzeżenie. Szczególnie wysoce niewłaściwa atmosfera, panująca w seminariach duchownych, jak również postawa społeczna młodego duchowieństwa, które w dużej mierze opuszcza rokrocznie zakłady teologiczne, wywołuje kategoryczny sprzeciw. W tej sytuacji brak jakiegokolwiek uzasadnienia do dalszego utrzymywania takiego uprzywilejowanego, a niezgodnego z wymogami prawa, stanu". List Premiera J. Cyrankiewicza do Episkopatu Polski w sprawie wprowadzenia nadzoru Państwa nad seminariami duchownymi z dnia 12 października 1959 r., [w:] P. Raina, op. cit., t. 1, s. 752 .

Na odpowiedź Episkopatu rząd nie musiał długo czekać, ponieważ już 29 października 1959 roku bp Z. Choromański odpowiedział na powyższy list, oświadczając w imieniu Episkopatu m.in.: „Wszystkie organy władzy powinny działać na podstawie przepisów prawa, jak tego wymaga art. 4 pkt 3 Konstytucji PRL — w tym wypadku powoływanie się na przytoczone ustawy nie może mieć zastosowania do seminariów duchownych. Powoływanie się na ustawę z dnia 11 marca 1932 roku w stosunku do seminariów duchownych nie jest słuszne ani uzasadnione z rozmaitych względów. Art. 10 tejże ustawy: »Ustawa niniejsza nie dotyczy prywatnych szkół akademickich [...]«. Właśnie seminaria wyższe są szkołami akademickimi, kształcą dorosłych po ukończeniu szkoły średniej. [...] Jako powód nadzoru Ministerstwa Oświaty i Urzędu do Spraw Wyznań Pan Premier podaje — »niewłaściwa atmosfera, panująca w seminariach duchownych, jak również postawa społeczna młodego duchowieństwa«. Nie wiadomo, co należy rozumieć pod określeniem niewłaściwej atmosfery i postawy społecznej — ale jest rzeczą dziwną i niezrozumiałą, że dotychczas w rozmowach między przedstawicielami rządu i Episkopatu ten zarzut nie był wysuwany. [...] Oczekujemy, że Pan Premier rozważy słuszne argumenty Episkopatu, zrewiduje swoje stanowisko i poweźmie decyzję zgodną z prawem”. List Episkopatu do Premiera J. Cyrankiewicza z odpowiedzia na pismo w sprawie wprowadzenia nadzoru nad Seminariami Duchownymi z dnia 29 października 1959 r., [w:] P. Raina, op. cit., s. 758-759.

Odpowiedź rządu została wysłana Episkopatowi w dniu 30 grudnia 1959 roku, a podnoszono w niej między innymi taki argument potwierdzający słuszność działania władz państwowych: 
WSD, zarówno diecezjalne, jak i zakonne, podporządkowano wówczas przepisom ustawy z dnia 19 kwietnia 1950 roku o zmianie organizacji naczelnych władz państwowych w zakresie gospodarki komunalnej i administracji publicznej ${ }^{16}$ oraz ustawy z dnia 11 marca 1932 roku o prywatnych szkołach, poddając je nadzorowi władz państwowych. Dokonano tego na mocy zarządzenia Ministra Oświaty z dnia 29 grudnia 1959 roku w porozumieniu z Urzędem do Spraw Wyznań (UdsW) ${ }^{17}$. Jednak, jak zaznacza Artur Mezglewski w swojej publikacji pt. Szkolnictwo wyznaniowe w Polsce w latach 1944-1980, ustawa z 11 marca 1932 roku o prywatnych szkołach nie mogła mieć zastosowania do zakładów naukowych kształcących dorosłych, jakimi były WSD, ponieważ nie wydano żadnego rozporządzenia wykonawczego, które pozwoliłoby stosować tę ustawę do tego rodzaju szkół, a przepisy ustawy o prywatnych szkołach nie nadawały się do bezpośredniego stosowania w stosunku do wyższych seminariów, gdyż nie uwzględniały ich specyfiki ${ }^{18}$. Mimo uchylenia tej ustawy nie wydano żadnych przepisów szczególnych dotyczących prowadzenia WSD, a zgodnie z przyjętą przez władze oświatowe wykładnią, wyższe seminaria diecezjalne i zakonne objęto zarządzeniem Ministra Oświaty z dnia 26 lutego 1965 roku w sprawie zasad i warunków prowadzenia niepaństwowych szkół i innych placówek oświatowo-wychowawczych ${ }^{19}$. UdsW uznał, iż wynikało to z faktu, że wyższe seminaria nie zostały objęte ustawą o szkolnictwie wyższym.

„Komunikuję, że argumentacja zawarta w piśmie Księdza Biskupa z dnia 20 (29!) października 1959 roku jest bezpodstawna i nie może być przyjęta do wiadomości przez władze państwowe. Nie może ona spowodować zmiany opartej na przepisach prawa decyzji o sprawowaniu nadzoru państwowego nad seminariami duchownymi, zakomunikowanej Episkopatowi pismem Prezesa Rady Ministrów z dnia 12 października 1959 roku. Jedynym uzasadnieniem niestosowania w okresie międzywojennym przepisów ustawy z dnia 11 marca 1932 roku o prywatnych szkołach oraz zakładach naukowych (Dz.U. Nr 33, poz. 343) do seminariów duchownych były przepisy art. XIII Konkordatu z 1925 roku. Konkordat przestał obowiązywać wskutek jednostronnego zerwania go przez Stolicę Apostolską przez akty prawne zdziałane w czasie okupacji, a sprzeczne z jego postanowieniami. Wobec utraty mocy obowiązującej przez konkordat, brakuje podstaw do wyłączenia seminariów spod działania przepisów ustawy z dnia 21 (11!) marca 1932 roku. Ustawa ta nie przewiduje żadnych wyjątków dla seminariów duchownych". List Petnomocnika Rządu do Spraw Stosunków z Kościołem J. Sztachelskiego do Sekretarza Episkopatu bp. Z. Choromańskiego w sprawie nadzoru państwowego nad seminariami duchownymi z dnia 30 grudnia 1959 r., [w:] P. Raina, op. cit., s. 768-771.

16 Dz.U. Nr 19, poz. 156.

17 A. Mezglewski, Proces likwidacji niższych seminariów duchownych w latach 1959-1963, „Studia z Prawa Wyznaniowego” 4, 2002, s. 33.

18 A. Mezglewski, Szkolnictwo wyznaniowe..., s. 73. Autor opracowania ponadto stwierdza, iż: 1. ustawy oświatowe z 11 marca 1932 roku nie odnosiły się i nie mogły dotyczyć wyższych seminariów duchownych; 2 . samo zarządzenie Ministra Oświaty wydane bez jakiejkolwiek delegacji ustawowej formalnie nie miało wpływu na sytuację prawną tych zakładów; 3. zarządzenie to pomimo swojej bezprawności miało jednak faktycznie zasadniczy wpływ na sytuację prawną tych zakładów.

19 M.P. Nr 13, poz. 483. 


\section{Lata $1960-1962$}

Wizytacje WSD władze oświatowe podjęły w lutym 1960 roku, ale na skutek protestów ze strony władz zakonnych początkowo spotkały się z dość dużym oporem. Zdarzały się bowiem sytuacje, że przełożeni seminariów nie udostępniali dokumentów albo w ogóle nie wpuszczali wizytatorów do budynków seminaryjnych ${ }^{20}$. W takich sytuacjach władze decydowały się zazwyczaj na drastyczne działania odwetowe, jak na przykład powoływanie do czynnej służby wojskowej lub zamknięcie seminarium ${ }^{21}$. Kolejnym działaniem było przeprowadzenie następnych wizytacji już o bardziej zdecydowanym charakterze ${ }^{22}$. Początkowo zapowiadano, iż wizytacje władz oświatowych będą dotyczyć jedynie przedmiotów o charakterze świeckim, lecz w rzeczywistości coraz częściej dochodziło do hospitacji przedmiotów także o charakterze religijnym.

Wizytacje w seminariach duchownych miały miejsce 1-3 razy w roku. Oficjalne sprawozdania ${ }^{23}$ zachowane w archiwach państwowych wskazują, że największą uwagę zwracano na warunki lokalowe, nastroje wśród kleryków, kadrę nauczycielską, stan majątkowy oraz prawdziwość danych podawanych przez seminaria w corocznych sprawozdaniach dla kuratoriów oświaty ${ }^{24}$. Nadzór nad seminariami realizowano przede wszystkim poprzez wizytacje pracowników kuratoriów oświaty oraz urzędników wydziałów do spraw wyznań wojewódzkich rad narodowych ${ }^{25}$.

UdsW opracowywał specjalne wytyczne, według których miały działać zespoły wizytujące $\mathrm{WSD}^{26}$. Zanim rozpoczęła się wizytacja, komisja była zobowiązana, by gruntownie przygotować się do kontroli w danym seminarium. Wizytacje miały odbywać się tylko w te dni, w których miały miejsce zajęcia z przedmiotów świeckich (socjologii, pedagogiki, psychologii, nauki o Polsce i świecie współczesnym itp.). Kontrolerzy sprawdzali podręczniki, skrypty, notatki alumnów, warunki lokalowe i sanitarne. Domagali się także udostępniania bibliotek, świetlic, sal wykładowych oraz pokojów alumnów. Celem tych kontroli nie było jednak podnoszenie kwalifikacji zawodowych wykładowców czy poziomu nauczania

${ }^{20}$ A. Mezglewski, Nadzór państwowy nad katolickimi seminariami duchownymi w okresie Polski Ludowej, „Studia z Prawa Wyznaniowego” 7, 2004 [2005], s. 85.

${ }^{21}$ Ibidem. Jak słusznie zauważa A. Mezglewski, władze państwowe nie miały do tego typu poczynań podstawy prawnej. Ustawa z 1932 roku o prywatnych szkołach nie przewidywała tego rodzaju sankcji, a to na nią najczęściej powoływały się władze państwowe.

22 Notatka Urzędu do Spraw Wyznań z 1960 r., [w:] Kościół katolicki a państwo w świetle dokumentów 1945-1989, t. 2. Lata 1960-1974, red. P. Raina, Poznań 1995, s. 39-40.

23 IPN Wr, sygn. akt 032/36 t. 2, Kontrwywiadowcza charakterystyka zagadnienia po linii reakcyjnego kleru katolickiego na terenie powiatu wrocławskiego z dnia 3 maja 1959 roku, k. 18-33.

24 A. Mezglewski, Nadzór państwowy..., s. 86.

25 A. Mezglewski, Szkolnictwo wyznaniowe..., s. 74.

26 B. Fijałkowska, Partia wobec religii Kościoła w PRL, t. 2, cz. 1. 1956-1963, Olsztyn 2000, s. $136-137$. 
w seminariach, lecz raczej opracowanie charakterystyk rektorów i wykładowców WSD. Przed rozpoczęciem każdej wizytacji WdsW organizowały spotkania instruktażowe na temat celu i zakresu wizytacji seminarium ${ }^{27}$. UdsW określił też tryb i sposób postępowania komisji wizytacyjnej na okoliczność niedopuszczenia do planowanej wizytacji. W związku z tym zachęcał wizytatorów do życzliwych rozmów z alumnami oraz pokojowego przeprowadzania kontroli. Wizytacja miała kończyć się rozmową z rektorem, podczas której chciano uzyskać informacje, jakie szkoły średnie kończyli alumni oraz z jakich miast pochodzili. Zasadniczym celem wizytacji była kontrola pracy dydaktyczno-wychowawczej, nastrojów panujących w seminarium, sprawdzenie księgozbiorów w bibliotekach ${ }^{28}$ — czy nie znajdują się w nim publikacje wrogie władzy ludowej — oraz kontrola dokumentacji (między innymi statutu WSD, regulaminu placówki, wykazu wykładowców oraz ich kwalifikacji i wykształcenia, wykazu alumnów, wykładanych przedmiotów, używanych podręczników i skryptów, czasopism polskich i zagranicznych, liczby tomów w bibliotece, dokumentacji opieki lekarskiej czy dokumentacji prac samorządu alumnów ${ }^{29}$. WSD objęto także obowiązkiem przesyłania corocznych sprawozdań z działalności oraz informacji o alumnach poborowych ${ }^{30}$.

Po przeprowadzonej wizytacji sporządzano sprawozdanie, które przesyłano do UdsW i WdsW, do seminarium zaś wysyłano jedynie odpowiednie zalecenia i wskazania. Władze polityczne interesowały się głównie oceną polityczną działalności danej placówki, a mianowicie czy ,seminarium przygotowuje przyszłych księży jako spolegliwych obywateli PRL-u, do lojalnej współpracy z władzami państwowymi w parafii, czy też edukuje na przeciwników ustroju i władzy ludowej"31.

Jak podaje A. Mezglewski we wcześniej wskazanej publikacji, w piśmie Pełnomocnika Rządu do Spraw Stosunków z Kościołem z grudnia 1960 roku mowa jest o ponad 80 zwizytowanych seminariach i o sporadycznych tylko próbach przeciwstawiania się ich przeprowadzeniu ${ }^{32}$.

W latach 1960-1962 komisje wizytujące były skupione głównie na przełamywaniu oporu tych rektorów seminariów, którzy nie chcieli wpuszczać ich na teren seminariów. Wizytatorzy przyglądali się także biernie nauczaniu dydaktycznemu w placówce. Przeprowadzono wówczas tylko częściową kontrolę dokumentacji

27 D. Zamiatała, op. cit., s. 591.

28 A. Mezglewski, Szkolnictwo wyznaniowe..., s. 74. W dniach 22-24 sierpnia 1960 roku w całej Polsce przeprowadzono kontrolę 67 bibliotek seminaryjnych, w wyniku której skonfiskowano 12 tys. woluminów. Kontrolę przeprowadzali przedstawiciele Urzędu Kontroli Prasy, Publikacji i Widowisk w asyście urzędników UdsW i Milicji Obywatelskiej. Była to jedyna kontrola bibliotek o zasięgu ogólnokrajowym. W latach późniejszych już nie przeprowadzano akcji na taką skalę, lecz UdsW zawsze interesował się, czy biblioteki nie zawierają pozycji antysocjalistycznych — A. Mezglewski, Szkolnictwo wyznaniowe..., s. 76.

29 D. Zamiatała, op. cit.; A. Mezglewski, Szkolnictwo wyznaniowe..., s. 74.

30 A. Mezglewski, Szkolnictwo wyznaniowe ..., s. 74.

31 D. Zamiatała, op. cit., s. 591-592.

32 A. Mezglewski, Szkolnictwo wyznaniowe..., s. 75. 
WSD i bibliotek. W tym czasie funkcjonariusze zapoznawali się z działalnością i funkcjonowaniem WSD, hospitowali niektóre przedmioty, analizowali plany studiów oraz przeprowadzali rozmowy z rektorami i wykładowcami. Wyciągając wnioski ze sprawozdań, władze państwowe sugerowały wprowadzenie dodatkowych zajęć z przedmiotów takich, jak nauka o Polsce i świecie współczesnym oraz państwowe prawo wyznaniowe. Opracowaniem podręczników z tych przedmiotów dla WSD miało się zająć Ministerstwo Oświaty.

Władze państwowe interesowały się także samymi kandydatami na alumnów. Jeśli do władzy państwowej dotarła informacja, że kandydat deklaruje chęć wstąpienia do seminarium duchownego lub do zgromadzenia zakonnego, budził on już zainteresowanie bezpieki i odtąd zbierano informacje na temat nie tylko jego samego, lecz także jego rodziny ${ }^{33}$. Władze państwowe kontrolowały następnie jego proces nauki, postawę moralną, zachowania w trakcie dni wolnych od zajęć dydaktycznych oraz przekonania społeczno-polityczne, by w razie czego, czy to dobrowolnie, czy też na skutek szantażu, zwerbować go jako tajnego współpracownika $^{34}$. Dokumenty archiwum Instytutu Pamięci Narodowej we Wrocławiu ukazują akcje służb specjalnych mające na celu inwigilację i destabilizację formacji i życia zakonnego w wielu seminariach zakonnych w Polsce. Przykład może tutaj stanowić chociażby wyższe seminarium duchowne w Bagnie, które musiało zmierzyć się z wieloma trudnościami i niebezpieczeństwami ze strony ówczesnych władz państwowych ${ }^{35}$.

W dniu 17 listopada 1960 roku Episkopat Polski opracował jednolite zasady postępowania wobec wizytatorów dla kierownictwa WSD, zgodnie z którymi można było udostępniać komisji wizytacyjnej jedynie wykazy profesorów, alumnów oraz plan dni wolnych od zajęć. Do wizytacji przedmiotów świeckich (historii doktryn i wprowadzonej w tym czasie do seminariów nauki o Polsce i świecie współczesnym) mogli dopuszczać dopiero pod presją ${ }^{36}$. Członkowie komisji wizytacyjnej nie mogli w ogóle hospitować przedmiotów teologicznych. Uznano za dopuszczalne udostępnianie kontrolerom tych dokumentów, które z natury swej są jawne, czyli wykazy alumnów, wykładowców, personelu — wraz z ich danymi osobowymi. Ponadto zezwalano na udostępnianie wykazu dni wolnych od zajęć dydaktycznych ${ }^{37}$.

33 A. Szymanowski, Polityka władz komunistycznych wobec Kościoła rzymskokatolickiego na Dolnym Śląsku w latach 1960-1966, Wrocław 2009, s. 81.

34 IPN Wr, sygn. akt 032/26 t. 1-3, Doniesienie kontaktu poufnego „Z” dot. ks. Kokoszki, który wykłada prawo kanoniczne w seminarium duchownym w Bagnie u księży salwatorianów, z dnia 14 listopada 1959 roku, k. 421.

35 Instytut Pamięci Narodowej Oddziałowe Biuro Udostępniania i Archiwizacji Dokumentów w Warszawie (IPN Bu), sygn. akt 01283/1181/J, Zakony męskie — Salwatorianie: materiały z lat 1957-1966; IPN Bu, sygn. akt 01283/1183/J, Zakony męskie — Salwatorianie: sprawa obiektowa „Bagno” z lat 1966-1971; IPN Bu, sygn. akt 01283/1186/J, Zakony męskie — Salwatorianie: Notatki służbowe, informacje.

36 D. Zamiatała, op. cit., s. 592.

37 A. Mezglewski, Szkolnictwo wyznaniowe..., s. 79. 


\section{Lata 1963-1966}

W roku akademickim 1963/1964 władze komunistyczne planowały rozszerzenie kontroli nad WSD oraz bezkonfliktowe hospitacje zajęć z przedmiotów teologicznych ${ }^{38}$, pomimo oficjalnych zapewnień, że im na tym nie zależy. UdsW przeprowadził wówczas rozmowy z rektorami seminariów, którzy nie kwestionowali uprawnień państwa do nadzoru nad zakonnymi seminariami.

Władze uważały wówczas, że seminaria duchowne powinny realizować ogólne założenia systemu oświaty i wychowania w PRL-u, zawarte w art. 1 ustawy z dnia 15 lipca 1961 roku o rozwoju systemu oświaty i wychowania ${ }^{39}$, który mówił, iż „nauczanie w szkołach i innych placówkach oświatowo-wychowawczych ma na celu wszechstronny rozwój uczniów i wychowanie ich na świadomych i twórczych obywateli Rzeczypospolitej Ludowej”. Ponadto przepis ten stwierdzał, że szkoły i inne placówki oświatowo-wychowawcze wychowują w duchu socjalistycznej moralności i socjalistycznych zasad współżycia społecznego, w duchu umiłowania Ojczyzny, pokoju, wolności, sprawiedliwości społecznej i braterstwa z ludźmi pracy wszystkich krajów, uczą zamiłowania i szacunku do pracy, poszanowania mienia narodowego oraz przygotowują do czynnego udziału w rozwoju kraju, jego gospodarki i kultury. W rezultacie ustawa ta przewidywała, że wiedza wykładana w szkole ma kształtować naukowy pogląd na świat, przez który twórcy ustawy rozumieli światopogląd materialistyczny ${ }^{40}$.

Poza tym rządzący uznali się za kompetentnych w kwestii zatwierdzania programów nauczania w WSD oraz kadr wykładowców. Zanim rozpoczął się rok akademicki 1964/1965, kuratoria domagały się od rektorów seminariów zakonnych dostarczenia do zatwierdzenia sprawozdania $\mathrm{z}$ organizacji roku szkolnego oraz listy wykładowców pracujących z alumnami ${ }^{41}$. Wiele z zakonnych WSD odmówiło państwu złożenia wypełnionych na ten rok arkuszy organizacyjnych, przesłanych im przez kuratoria, uznając za jedyną kompetentną $\mathrm{w}$ tym zakresie władzę kościelną. Wynikało to zapewne również z faktu, że WSD obawiały się sytuacji, w której władze państwowe nie zatwierdzą danej uczelni, co będzie jednoznaczne z jej likwidacją. Władze państwowe uparcie próbowały wyegzekwować ten wymóg, co kończyło się często tym, że seminaria wysyłały władzom państwowym listy wykładowców tylko do wiadomości.

W roku szkolnym 1964/1965 doszło w sumie do wizytacji 28 WSD (13 zakonnych i 15 diecezjalnych). Miały one na celu przede wszystkim kontrolę po-

38 Ibidem, s. 75: „W roku 1963 co najmniej w kilku przypadkach komisje wizytujące seminaria domagały się przeprowadzenia hospitacji przedmiotów ściśle teologicznych".

39 Dz.U. Nr 32, poz. 160.

40 M. Pietrzak, Prawo wyznaniowe, Warszawa 2013, s. 175.

41 A. Kiełbasa, Represje wobec salwatorianów na Dolnym Śląsku w latach 1945-1956, [w:] Represje wobec Kościoła katolickiego na Dolnym Ślasku i Opolszczyźnie 1945-1989, red. A. Bogaczewicz, S. Krzyżanowska, Wrocław 2004, s. 113-124. 
staw rektorów. Jak podaje Dominik Zamiatała w tomie 1 o tytule Problematyka organizacyjno-personalna publikacji pt. Zakony męskie w polityce władz komunistycznych $w$ Polsce $w$ latach 1945-1989, doszło do wizytacji tylko 5 WSD zakonnych i 4 WSD diecezjalnych ${ }^{42}$. W zależności od przeprowadzonych rozmów planowano podjęcie środków represyjnych wobec niektórych WSD, na przykład nazajutrz po rozmowie z danym rektorem przeprowadzenie kontroli finansowej, urządzeń przeciwpożarowych, sanitarnych i bibliotek. Sankcją za niepodporządkowanie się przepisom mogło być również zawieszenie działalności placówki lub kierowanie alumnów do służby wojskowej ${ }^{43}$. Natomiast ci rektorzy WSD, którzy podpisali deklarację lojalności wobec władz państwowych, mogli cieszyć się tym, że w roku 1965 ich WSD nie będzie objęte kontrolą.

Od roku 1965 władze państwowe podczas rozmów z rektorami informowały ich o wprowadzonym przez nie obowiązku zatwierdzania rektorów i wykładowców. Żądały także podporządkowania się WSD nadzorowi państwa, postawienia na należytym poziomie $\mathrm{w}$ seminariach obywatelskiego wychowania alumnów i zapoznania ich z osiągnięciami ustroju socjalistycznego w dziedzinie gospodarczej i społecznej, odpowiedniego prowadzenia wykładów z zakresu wiadomości o Polsce i świecie współczesnym oraz prawa wyznaniowego, a także konsekwentnego wpajania alumnom zasad lojalnego przestrzegania przepisów państwowych.

Prerogatywy władz państwowych co do nadzoru w większości przypadków nie były kwestionowane przez rektorów seminariów. Co więcej, często wyrażali oni również swoją lojalność wobec władz państwowych. Zdarzały się jednak wypadki, że rektorzy przeciwstawiali się poczynaniom władz państwowych i wysuwali zarzuty nadużywania przez funkcjonariuszy bezpieki swojej pozycji. Funkcjonariuszy oskarżano między innymi o nachodzenie wykładowców seminariów w ich domach w okresie wakacyjnym, werbowanie kleryków do współpracy agenturalnej, nakładanie podatków na seminaria i opodatkowanie wyżywienia $\mathrm{WSD}^{44}$, czy też pobór kleryków do wojska i wzywanie do siedziby służb na rozmowy ${ }^{45}$.

42 D. Zamiatała, op. cit., s. 594.

43 A. Szymanowski, op. cit., s. 83. Podczas odbywania przez alumnów zasadniczej służby wojskowej szpiegowano ich, kontrolowano ich korespondencję wychodzącą i przychodzącą, podsłuchiwano rozmowy, organizowano system donosów i niepokojów wśród alumnów przy pomocy tajnych współpracowników i innych donosicieli.

44 „Wyżywienie kleryków w Diecezjalnych Seminariach Duchownych z funduszy kościelnych zebranych z wyraźnym przeznaczeniem »na utrzymanie« (tj. głównie też wyżywienie) Sem. (inarium) Duch.(ownego), winno być uznane za wydatek na cele kultu religijnego. Ofiary na ten cel, wyraźnie przez wiernych oznaczony, przeznaczone być winny na Seminaria Duchowne, a opodatkowanie ich podatkiem $65 \%$ uznać należy za sprzeciwianie się woli ofiarodawców, za aspołeczne. [...] Nieuznanie Seminariów Duchownych Zakonnych jako osoby prawnej, a w każdym razie nieuznanie wydatków na te Seminaria, jest oczywistym brakiem rozeznania sprawy". List Episkopatu do Petnomocnika Rządu do Spraw Stosunków z Kościołem J. Sztachelskiego w sprawie opodatkowania duchowieństwa z dnia 2 października 1959 r., [w:] P. Raina, op. cit., s. 748.

45 B. Fijałkowska, Partia wobec religii Kościoła w PRL, t. 2, cz. 2. 1964-1970, s. 259; I. Kiełbasa, 60-lecie Wyższego Seminarium Duchownego Salwatorianów w Bagnie (1953-2013), „Studia Salvatoriana Polonica" 7, 2013, s. 34.

Prawo 325, 2018

(C) for this edition by CNS 
Rozmowy władz z rektorami zakonnymi i diecezjalnymi WSD pozwoliły na zakwalifikowanie rektorów do konkretnej grupy charakterystycznej, a mianowicie podzielono ich na trzy grupy według postaw:

1. zdecydowanie wroga wobec wizytacji, która nie uznawała żadnych przepisów w tej kwestii, negująca prawo państwa do przeprowadzania wizytacji i uznająca bez zastrzeżeń zarządzenia Episkopatu;

2. umiarkowana, wyrażająca się tym, iż rektorzy, nie chcąc narażać się władzom państwowym, omijali zarządzenia Episkopatu, co przeważnie oznaczało, że nie kwestionowali oni prawa do wizytacji, lecz jedynie do jej zakresu;

3. rektorzy, którzy jawnie łamali polecenia Episkopatu i wypełniali wszystkie nakazy władz państwowych w zakresie wizytacji WSD ${ }^{46}$.

Ponadto, dzięki wizytacjom UdsW dowiedział się, jak w przyszłości należy współpracować i postępować z rektorami, by byli przychylni zarządzeniom władz.

W marcu 1965 roku UdsW przeprowadził rozmowy indywidualne z prowincjałami zakonnymi i zgromadzeń zakonnych na temat listu bpa Zygmunta Choromańskiego z 28 grudnia 1964 roku, by ustalić, które WSD nie podporządkują się nadzorowi państwowemu, i zastosować wobec tych placówek sankcje karne (na przykład zawieszenie działalności na czas nieokreślony). Te seminaria, które wyrażały postawę lojalnościową, mogły liczyć na zwolnienie z podatku dochodowego od wyżywienia kleryków. Okazało się, że rozmowy te zakończyły się sukcesem UdsW, gdyż większość placówek zgodziła się na wizytacje. Stanowiło to dużą rozbieżność między stanowiskiem biskupów i prowincjałów zakonnych, co władze komunistyczne wykorzystywały na własną korzyść i we własnych celach ${ }^{47}$.

W kwestii nadzoru nad seminariami w Polsce UdsW w kolejnych latach także wzywał na rozmowy rektorów WSD w celu zmuszenia ich do dopuszczania do wizytacji seminariów przez władze państwowe. Prowadzenie częstych rozmów miało wpłynąc na osłabienie woli rektorów w kwestii przeciwstawiania się władzom państwowym oraz przywyknięcie do wizytacji. Działalność ta przynosiła wymierne efekty.

W latach 1963-1968 stosunek WSD do nadzoru państwowego był niejednolity, gdyż władze państwowe z jednej strony napotykały opór rektorów czy przełożonych zakonnych, a z drugiej przeprowadzały wizytacje bez żadnych trudności. Część rektorów wyższych seminariów i prowincjałów zakonnych do roku 1964 nie stwarzała trudności i zgadzała się na nadzór państwa nad ich seminariami oraz hospitowanie przez komisje przedmiotów świeckich. Rok 1965 przyniósł pewne zmiany w tym zakresie na skutek kategorycznego zakazu Episkopatu wobec wizytacji WSD i grożenia sankcjami kościelnymi wobec tych seminariów, które się temu zakazowi przeciwstawią.

W późniejszych latach, mimo obowiązującego zakazu Episkopatu, władze — za zgodą prowincjałów - wizytowały WSD werbistów, misjonarzy Świętej

46 D. Zamiatała, op. cit., s. 596.

47 Ibidem, s. 598: „na 24 WSD zakonne, na wizytację państwową pozwoliło 15 seminariów”. 
Rodziny, franciszkanów, pallotynów, oblatów i redemptorystów ${ }^{48}$, co doprowadziło do ponowienia w marcu 1966 roku przez Episkopat Polski kategorycznego zakazu dopuszczania władz komunistycznych do wizytacji WSD. Skutkowało to zaostrzeniem stanowiska wobec wizytacji nawet przychylnych wobec władz prowincjonałów i rektorów WSD.

W okresie od 3 marca do 29 kwietnia 1966 roku UdsW podjął próbę zwizytowania 28 WSD, w tym 17 WSD zakonnych. Udało się to jednak jedynie w wypadku 8 WSD. Kontrole przeprowadzono w trzech fazach: I - od 3 do 5 marca, II — od 29 do 31 marca, III — od 22 do 23 kwietnia $^{49}$. Wizytacje w tym czasie miały na celu przede wszystkim hospitację wykładów oraz kontrolę wiadomości kleryków. Rektorzy WSD oraz prowincjonałowie mieli świadomość, że nie dopuszczając do wizytacji, narażają się na sankcje ze strony państwa, natomiast dopuszczając do nich — na sankcje ze strony Episkopatu Polski.

\section{Lata $1967-1971$}

W roku szkolnym 1968/1969 władzom państwowym udało się przeprowadzić wizytacje kilku WSD zakonnych mimo obowiązującego zakazu prymasa kard. Stanisława Wyszyńskiego. Te placówki, które wyraziły zgodę na wizytację, były bardzo pozytywnie oceniane przez władze państwowe i zostały wynagrodzone zwolnieniem z podatku dochodowego od wyżywienia alumnów.

Do innych postaci nadzoru w tym czasie należy zaliczyć obowiązek przekazywania szczegółowych rocznych sprawozdań z działalności seminarium (obejmowały one dane dotyczące alumnów, wykładowców wraz z przydziałem godzin lekcyjnych, pracowników służby zdrowia, personelu administracyjnego i pomocniczego, organizacji seminarium, tygodniowego rozkładu zajęć naukowych i wychowawczych) oraz rozmowy z kierownictwem seminariów, przeprowadzanych również poza wizytacjami, w trakcie których kierownictwo seminariów udzielało potrzebnych wyjaśnień. W latach 70 . zaprzestano regularnych wizytacji i ,nieformalne" kontakty z przełożonymi seminariów były praktycznie jedyną formą sprawowania nadzoru ${ }^{50}$.

$\mathrm{Na}$ początku lat 70 . wyniki przeprowadzonych wizytacji wykazały, że cel nie został osiągnięty. Pomimo stosowania wielu nacisków władze komunistyczne natrafiały na trudności z przeprowadzeniem kontroli, co w dużej mierze wynikało też ze słabego przygotowania kadry wizytatorów. Program WSD diecezjalnych i zakonnych nie był zatwierdzony przez państwo poniekąd dlatego, że komisje wizytacyjne nie ustosunkowały się do programu nauczania WSD. Ponadto władzom pań-

48 D. Zamiatała, op. cit., s. 602.

49 Ibidem.

50 A. Mezglewski, Szkolnictwo wyznaniowe..., s. 77. 
stwowym nie udało się rozpoznać postaw społeczno-politycznych wykładowców, a także dowiedzieć się, z jakich szkół pochodzą klerycy, by zahamować dopływ nowych kandydatów z tych placówek do WSD, co miało wspomóc akcję laicyzacyjną.

Episkopat Polski stał w totalnej opozycji do nadzoru państwowego nad WSD. Kardynał Wyszyński uznawał mieszanie się państwa w wewnętrzne sprawy Kościoła, jakim jest przygotowanie kandydatów do kapłaństwa, za sprzeczne z konstytucyjną wolnością religijną. Biskupi uważali, że celem wizytacji WSD jest tak na prawdę tropienie niedociągnięć i dowodów do przyszłej likwidacji tych placówek, a nie — jak deklarowała władza państwowa - troska o poziom nauczania i wychowania przyszłej kadry duchowieństwa.

W latach 1960-1971 na terenie całej Polski władze państwowe przeprowadzały wizytacje w wyższych seminariach diecezjalnych i zakonnych. W zależności od placówki oraz roku udawało się to z mniejszym lub większym skutkiem. Warte podkreślenia jest, że im mocniej protestował Kościół, tym większa była determinacja władz państwowych $\mathrm{w}$ tej sprawie ${ }^{51}$. W pierwszej połowie lat 60 . władzom udało się złamać opór Episkopatu Polski, który przystał na to, by wizytatorzy hospitowali zajęcia $\mathrm{z}$ przedmiotów świeckich ${ }^{52}$; odmówił natomiast hospitacji przedmiotów teologicznych, co było często łamane przez komisje wizytacyjne. W roku akademickim 1963/1964 władze kościelne podjęły próbę porozumienia z władzami państwowymi, co we wrześniu 1964 roku zaowocowało tym, że sekretariat Episkopatu uzgodnił z UdsW przedmioty świeckie, które mogły podlegać wizytacji państwa za zgodą ordynariuszy. Opierając się na tym postanowieniu, Ministerstwo Oświaty miało wydać regulamin wizytacji. Jak się później okazało, terenowe władze administracyjne nie respektowały tych uzgodnień i UdsW wycofał się ze swych zobowiązań dotyczących regulaminu ${ }^{53}$.

Pod koniec 1964 roku stanowisko biskupów zmieniło się. Sekretarz Episkopatu 28 grudnia 1964 roku, powołując się na podpisaną przez Polskę dnia 13 lipca 1964 roku Konwencję paryską z dnia 15 grudnia 1960 roku (ratyfikowaną przez Polskę 14 grudnia 1964 roku) w sprawie zwalczania dyskryminacji w dziedzinie oświaty ${ }^{54}$, uznał, że działania władz polegające między innymi na wizytowaniu wyższych seminariów są nielegalne i państwo nie ma żadnego prawa ingerencji $\mathrm{w}$ system nauczania alumnów w seminariach duchownych - w związku z tym zakazał kategorycznie wizytacji WSD oraz hospitacji przedmiotów świeckich ${ }^{55}$.

51 B. Fijałkowska, op. cit., t. 2, cz. 1, s. 136-137.

52 A. Mezglewski, Szkolnictwo wyznaniowe..., s. 77. Należy podkreślić, że na przełomie lat 50. i 60. władze państwowe stawiały sobie daleko idące cele, dążąc do całkowitego podporządkowania Kościoła i pełnej kontroli nad seminariami duchownymi, pod względem zarówno treści wykładanych tam przedmiotów, jak i wpływu na obsadę personalną. Opór Kościoła był jednak duży, a postawa Episkopatu zdecydowana, dlatego też oczekiwania władz musiały być stopniowo minimalizowane.

53 D. Zamiatała, op. cit., s. 605.

54 Dz.U. Nr 40, poz. 268.

55 A. Mezglewski, Szkolnictwo wyznaniowe..., s. 79. 
W odpowiedzi władze państwowe uznały, że Kościół narusza porządek prawny PRL-u, ponieważ konwencja ta nie przekracza w niczym ogólnie przyjętej zasady nadzoru państwa nad wszelkimi placówkami oświatowymi ${ }^{56}$.

Sytuacja polskich seminariów duchownych stała się następnego roku przedmiotem niepokoju Stolicy Apostolskiej, która w liście do biskupów ordynariuszy z dnia 14 maja 1965 roku uznała, że mimo iż władze państwowe w Polsce wszem i wobec rozgłaszają, że gwarantują wolność religijną oraz rozdział Kościoła od państwa, w rzeczywistości ingerują w wewnętrzne sprawy Kościoła. Watykan przypomniał ponadto o naturalnym i własnym prawie Kościoła do kształcenia kandydatów do kapłaństwa według zasad wynikających z doktryny Kościoła, a także o tym, iż prawo to respektowane jest przez wszystkie narody - nawet pierwotne i niechrześcijańskie ${ }^{57}$.

W dniu 30 grudnia 1966 roku podczas posiedzenia Komisji Wspólnej Rządu i Episkopatu doszło do porozumienia i przyjęto normę nadzoru nad WSD. Podkomisji zlecono opracowanie szczegółowe zakresu i form nadzoru. Na kolejnym posiedzeniu Komisji Wspólnej w dniu 20 stycznia 1967 roku podtrzymano te ustalenia. Rząd opracował wówczas projekt regulaminu wykonywania nadzoru nad WSD, który stanowił między innymi, że celem nadzoru państwowego nad WSD jest czuwanie nad kształceniem alumnów w przedmiotach świeckich mających wpływ na wychowanie obywatelskie i zapewniających wiedzę o państwie polskim, jego gospodarce i kulturze, a także iż nauczanie oraz kształcenie nie powinno stać w sprzeczności z zasadami Konstytucji PRL, porządkiem prawnopublicznym i ustrojem państwa. Zastrzegał również, że przedmiotem nadzoru nie będzie nauczanie teologiczne i wychowanie religijne alumnów ${ }^{58}$.

Episkopat nie przedstawił własnego projektu regulaminu, a w dyskusji nad projektem rządowym podważył prawo nadzoru państwa nad WSD. Biskupi przeciwstawili się temu, aby ustawa o rozwoju oświaty i wychowania z 1961 roku obejmowała także kandydatów na kapłanów. Ponadto nie zgadzali się na wychowywanie przyszłych kapłanów w duchu socjalistycznym. Projekt państwowego regulaminu seminarium zawierał ponadto sankcje karne za jego nieprzestrzeganie. Biskupi byli też zdania, że wgląd w obywatelskie wychowanie w seminariach powinno mieć Ministerstwo Oświaty, a nie $\mathrm{UdsW}^{59}$.

Rozmowy w kwestii nadzoru nad działalnością WSD były prowadzone w podkomisji w ramach Komisji Mieszanej Rządu i Episkopatu. Po kilku spotkaniach rozmowy przerwano i nadzór nad WSD uległ zawieszeniu — ostatecznie w 1971 roku władze państwowe zaprzestały wizytacji WSD.

56 D. Zamiatała, op. cit.

57 A. Mezglewski, Szkolnictwo wyznaniowe..., s. 80.

58 D. Zamiatała, op. cit., s. 607.

59 Ibidem. 


\section{Zakończenie}

Reasumując, należy podkreślić, że wprowadzenie nadzoru państwowego nad WSD stanowiło naruszenie konstytucyjnej zasady rozdziału Kościoła od państwa (art. 70 ust. 2 Konstytucji PRL). Mimo iż konstytucyjny zapis wprowadzający tę zasadę był dość lakoniczny, gdyż stwierdzał jedynie, że „Kościół jest oddzielony od państwa", oraz nie precyzował charakteru tego rozdziału, to jednak wprowadzony w 1959 roku nadzór zakładający wpływ państwa na przykład na opracowywanie programów nauczania, wizytacje czy obsadę stanowisk wykładowców przeczył jakiemukolwiek modelowi rozdziału.

Polityka państwa wobec seminariów duchownych po roku 1959 stanowi wyraźny przykład łamania konstytucyjnych przepisów deklarujących rozdział Kościoła od państwa, ponieważ w praktyce działał system zwierzchnictwa państwa nad Kościołem w niespotykanych dotąd rozmiarach ${ }^{60}$.

Na koniec należy jeszcze zaznaczyć, że prowadzenie wizytacji w WSD w zasadzie nie przyniosło skutków ujemnych dla samych placówek, gdyż wizytacje zazwyczaj nie wykrywały żadnych większych nieprawidłowości ${ }^{61}$. Nie stanowiły też podstawowego źródła informacji o seminariach. Odmowa zaś zgody na wizytację seminarium spotykała się z niezwykle niebezpiecznymi reperkusjami, jak na przykład powoływanie większej grupy alumnów tego seminarium do służby wojskowej czy też obostrzenie wymiarów podatkowych ${ }^{62}$.

Jak zaznacza A. Mezglewski, w kwestii faktycznych możliwości zakładania i prowadzenia WSD Kościoła katolickiego — w przeciwieństwie do seminariów niższych — „w całym okresie Polski Ludowej nie było takiego momentu, w którym władze starałyby się ograniczyć ich liczbę bądź zakazać ich tworzenia"63, co nie oznacza oczywiście, że ośrodki te mogły rozwijać się bez przeszkód.

60 H. Misztal, op. cit., s. 222-223; M. Miławicki, Dominikanie w Polsce po II wojnie światowej - stan badań, [w:] Komunistyczny aparat represji wobec polskiej prowincji Dominikanów, red. M. Miławicki, M. Wenklar, seria „Kościół w Okowach”, Kraków 2015, s. 7-43.

61 IPN Wr, sygn. akt 032/26 t. 1-3, Notatka Informacyjna Zastępcy Komendanta Wojewódzkiej Komendy Milicji Obywatelskiej Służby Bezpieczeństwa we Wrocławiu dotycząca obecnej sytuacji wśród kleru zakonnego salwatorianów w wyższym seminarium duchownym w Bagnie, z dnia 4 sierpnia 1958 roku, k. bd.

62 A. Mezglewski, Szkolnictwo wyznaniowe..., s. 81; Wyższe Seminarium Duchowne w NysieOpolu 1949-1999. Księga Jubileuszowa, red. K. Dola, J. Waloszek, Opole 2000.

63 Ibidem, s. 84. Liczba wyższych seminariów duchownych w okresie Polski Ludowej była zatem podobna — istniały 24 (26) wyższe seminaria diecezjalne oraz 24 zakonne. 


\section{Bibliografia}

\section{Archiwalia}

\section{Instytut Pamięci Narodowej Oddziałowe Biuro Udostępniania i Archiwizacji Dokumentów w Warszawie}

IPN Bu, sygn. 01283/1181/Jacket: Aktotwórca: Ministerstwo Spraw Wewnętrznych. Tytuł teczki: Zakony męskie — Salwatorianie: materiały z lat 1957-1966.

IPN Bu, sygn. 01283/1183/Jacket: Aktotwórca: Ministerstwo Spraw Wewnętrznych. Tytuł teczki: Zakony męskie - Salwatorianie: sprawa obiektowa „Bagno” z lat 1966-1971.

IPN Bu, sygn. 01283/1186/Jacket: Aktotwórca: Ministerstwo Spraw Wewnętrznych. Tytuł teczki: Zakony męskie — Salwatorianie: Notatki służbowe, informacje.

\section{Instytut Pamięci Narodowej Oddział we Wrocławiu}

IPN Wr, sygn. 032/26 t. 1-3. Aktotwórca: WUSW we Wrocławiu Tytuł teczki: Zagadnienia kleru. $1957-1963$.

IPN Wr, sygn. 032/36 t. 2. Aktotwórca: brak Tytuł teczki: IV-37.

\section{Akty prawne}

Ustawa z dnia 11 marca 1932 roku o prywatnych szkołach oraz zakładach naukowych i wychowawczych, Dz.U. RP Nr 33, poz. 343.

Ustawa z 11 marca 1932 roku o ustroju szkolnictwa, Dz.U. RP Nr 38, poz. 389.

Ustawa z 22 lutego 1937 roku o prywatnych szkołach wyższych, Dz.U. RP Nr 13, poz. 89.

Dekret z 28 października 1947 roku o organizacji nauki i szkolnictwa wyższego, Dz.U. Nr 66, poz. 415.

Ustawa z dnia 19 kwietnia 1950 roku o zmianie organizacji naczelnych władz państwowych w zakresie gospodarki komunalnej i administracji publicznej, Dz.U. Nr 19, poz. 156.

Dekret z dnia 9 lutego 1953 roku o obsadzaniu stanowisk duchownych, Dz.U. Nr 9, poz. 32.

Ustawa z dnia 15 lipca 1961 roku o rozwoju systemu oświaty i wychowania, Dz.U. Nr 32, poz. 160.

Zarządzenie Ministra Oświaty z dnia 29 grudnia 1959 roku wydane w porozumieniu z Urzędem do Spraw Wyznań w sprawie nadzoru nad seminariami duchownymi.

Zarządzenie Ministra Oświaty z dnia 26 lutego 1965 roku w sprawie zasad i warunków prowadzenia niepaństwowych szkół i innych placówek oświatowo-wychowawczych, M.P. Nr 13, poz. 483.

\section{Akty prawne międzynarodowe}

Konwencja paryska z dnia 15 grudnia 1960 roku w sprawie zwalczania dyskryminacji w dziedzinie oświaty wydana przez Polskę dnia 13 lipca 1964 roku (ratyfikowana 14 grudnia 1964 roku), Dz.U. Nr 40, poz. 268. 


\section{Literatura}

Fijałkowska B., Partia wobec religii Kościoła w PRL, t. 2, cz. 1. 1956-1963, Olsztyn 2000.

Fijałkowska B., Partia wobec religii Kościoła w PRL, t. 2, cz. 2. 1964-1970, Olsztyn 2001.

Kiełbasa I., 60-lecie Wyższego Seminarium Duchownego Salwatorianów w Bagnie (1953-2013), „Studia Salvatoriana Polonica” 7, 2013.

Kiełbasa A., Represje wobec salwatorianów na Dolnym śląsku w latach 1945-1956, [w:] Represje wobec Kościoła katolickiego na Dolnym Ślasku i Opolszczyźnie 1945-1989, red. A. Bogaczewicz, S. Krzyżanowska, Wrocław 2004.

Koredczuk J., Zarządzanie prywatnymi szkołami wyższymi w Polsce $w$ okresie międzywojennym, [w:] Zarządzanie szkoła wyższa, red. J. Blicharz, A. Chrisidu-Budnik, A. Sus, Wrocław 2004.

Mezglewski A., Nadzór państwowy nad katolickimi seminariami duchownymi w okresie Polski Ludowej, „Studia z Prawa Wyznaniowego" 7, 2004 [2005].

Mezglewski A., Proces likwidacji niższych seminariów duchownych w latach 1959-1963, „Studia z Prawa Wyznaniowego" 4, 2002.

Mezglewski A., Szkolnictwo wyznaniowe w Polsce w latach 1944-1980, Lublin 2004.

Miławicki M., Dominikanie w Polsce po II wojnie światowej — stan badań, [w:] Komunistyczny aparat represji wobec polskiej prowincji Dominikanów, red. M. Miławicki, M. Wenklar, seria „Kościół w Okowach”, Kraków 2015.

Misztal H., Polskie prawo wyznaniowe, Zagadnienia wstepne. Rys historyczny, t. 1, Lublin 1996.

Pietrzak M., Prawo wyznaniowe, Warszawa 2013.

Raina P., Kościót katolicki a państwo w świetle dokumentów 1945-1989, t. 1. Lata 1945-59, Poznań 1994.

Raina P., Kościół katolicki a państwo w świetle dokumentów 1945-1989, t. 2. Lata 1960-1974, Poznań 1995.

Szymanowski A., Polityka władz komunistycznych wobec Kościoła rzymskokatolickiego na Dolnym Ślasku w latach 1960-1966, Wrocław 2009.

Szymański A., Inwigilacja kadry i alumnów Wyższego Seminarium Duchownego we Wroctawiu przez Urząd Bezpieczeństwa Publicznego w latach 1953-1954, „Przegląd Prawa Wyznaniowego" 10, 2018.

Wyższe Seminarium Duchowne w Nysie-Opolu 1949-1999. Księa Jubileuszowa, red. K. Dola, J. Waloszek, Opole 2000.

Zamiatała D., Zakony męskie w polityce władz komunistycznych w Polsce w latach 1945-1989, t. 1. Problematyka organizacyjno-personalna, Łomianki 2011.

Związek J., Z dziejów Częstochowskiego Seminarium Duchownego w Krakowie (1926-1991), „Veritati et Caritati" 6, 2016.

\section{Inspections of seminars by state authorities in Poland in 1960-1971}

\section{Summary}

In 1960-1971 the government conducted inspections of seminars, both diocesan seminars and those run by religious orders, all over Poland. The success of the authorities' efforts depended on the seminar in question and the year. As early as in February 1950 the first attempts were made to subordinate some seminars to state control, specifically, the control of the Ministry of Education, on the basis of Articles 96-107 of the Decree 28 October 1947, which dealt with the organisation of schools and higher education institutions. The remaining seminars were to be controlled by the respective Boards of Education, in accordance with the Private Schools Act of 11 March 1932. Invoking these legislative acts, the authorities wanted to exercise the right to grant approval to statutes, curricula,

Prawo 325, 2018

(C) for this edition by CNS 
appointment of teaching staff as well as supervise the implementation of the curricula in the seminars. Yet their efforts produced meagre results. This did not change until 1959, when the communist authorities realised that freedom of educating and forming future priests was extremely problematic for them and that the process was completely out of their control. A conviction that in its seminars the Church was educating future priests in an atmosphere that was hostile to the people's republic and was promoting views hostile to the interests of society prompted the communist authorities to take action seeking to take control of seminars. The seminars were to abide by the provisions of the Act of 19 April 1950 on the Change of the Organisation State Authorities with Regard to Municipal and Public Administration, Private Schools Act of 11 March 1932, and then the Act of 15 July 1961 on the Development of the Education System as well as the Ordinance of the Minister of Education of 26 February 1965 on the Rules and Conditions of Running Non-State Schools and Other Education Institutions. They were also subordinated to the control of the state authorities. After more than a decade of battles between the government and the Polish Episcopate, the question of control over seminars was finally resolved in 1971, when the authorities ceased their inspections of seminars.

Keywords: clergy, Catholic Church, state control, People's Poland, inspections, seminary

\section{Visitationen der höheren Priesterseminare durch staatliche Behörden in Polen in den Jahren 1960-1971}

\section{Zusammenfassung}

In den Jahren 1960-1971 führten staatliche Behörden auf dem ganzen Gebiet Polens Visitationen in den höheren Seminaren der Diözesen und der Orden durch. Bereits im Februar 1950 versuchte man, einen Teil der Priesterseminare der Kontrolle des Staates, also des Ministeriums für Bildung und Erziehung auf Grund der Art. 96-107 des Dekretes vom 28. Oktober 1947, die die Organisation der Wissenschaft und des höheren Schulwesens betreffen, zu unterziehen. Die restlichen höheren und kleinen Seminare sollten der Kontrolle der Schulkuratorien gemäß dem Gesetz vom 11. März 1932 über Privatschulen und wissenschaftliche sowie erzieherische Einrichtungen unterliegen. Aufgrund dieser Rechtsakte wollten die Behörden über das Recht verfügen, die Satzungen, Programme und Unterrichtspläne zu bestätigen, das Lehrpersonal zu berufen und die Ausübung der Programme in den Seminaren ständig zu kontrollieren, was ihnen jedoch nicht gelang. Eine Änderung erfolgte erst im Jahre 1959, als die kommunistischen Behörden sich dessen bewusst wurden, dass die Freiheit des Unterrichtes und der Erziehung der Priesterkandidaten eine sehr heikle und durch den Staat nicht kontrollierte Angelegenheit blieb. Aufgrund der Überzeugung, dass die Ausbildung in den Seminaren in einer staatsfeindlichen Atmosphäre verläuft und dort Meinungen gefördert werden, die sozialfeindlich sind, haben die Volksbehörden Maßnahmen zur Kontrolle der höheren Priesterseminare getroffen. Die höheren Priesterseminare wurden damals dem Gesetz vom 19. April 1950 über die Änderung der Organisation der obersten Staatsbehörden im Bereich der kommunalen Wirtschaft und der öffentlichen Verwaltung, dem Gesetz vom 11. März 1932 über Privatschulen und weiterhin dem Gesetz vom 15. Juli 1961 über die Entwicklung des Bildungssystems und Erziehungswesens und der Verordnung des Kultusministers vom 26. Februar 1965 in Sachen der Grundsätze und Bedingungen der Führung nicht staatlicher Schulen und anderer schulischer und pädagogischer Zentren unterordnet sowie der Aufsicht staatlicher Behörden unterzogen. Nach mehr als zehn Jahren eines Kampfes zwischen den Staatsbehörden und dem Episkopat Polens wurde die Aufsicht über die höheren Priesterseminare endgültig im Jahre 1971 eingestellt.

Schlüsselworte: Klerus, katholische Kirche, staatliche Aufsicht, Volksrepublik Polen, Visitationen, höhere Priesterseminare

Prawo 325, 2018

(C) for this edition by CNS 